\title{
Serum FSH-suppressing activity of human recombinant inhibin $A$ in male and female rats
}

\author{
D. M. Robertson, M. Prisk*, J. W. McMaster*, D. C. Irby, J. K. Findlay* \\ and D. M. de Kretser \\ Department of Anatomy, Monash University, Clayton, Victoria 3168, Australia; and *Prince \\ Henry's Institute of Medical Research, PO Box 118, South Melbourne, Victoria 3205, Australia
}

\begin{abstract}
Summary. After a single i.v. injection of purified human recombinant inhibin A (hrinhibin) or bovine follicular fluid (bFF) to 3-day castrated 35-day-old male rats, serum FSH concentrations fell $(P<0.05)$ between 4 and $8 \mathrm{~h}$, returning to control concentrations by $16-24 \mathrm{~h}$. Administration of graded doses of hr-inhibin $(0 \cdot 625-10 \mu \mathrm{g} / 100 \mathrm{~g}$ body $w t)$ and bFF (31-3-250 $\mu \mathrm{l} / 100 \mathrm{~g}$ body $w \mathrm{t})$ resulted in a parallel dose-related suppression of serum FSH with a maximum suppression $50 \%$ of controls. Similar experiments in 2-day ovariectomized 85-day-old female rats also showed a dose-related suppression with a maximum suppression approximately $30 \%$ of controls. Serum LH concentrations remained unchanged in all studies with male or female rats.

The biological activity of hr-inhibin in vivo was determined for male and female rats in terms of a standard bFF preparation defined by an in-vitro bioassay based on the suppression of FSH content in rat pituitary cells in culture. In males hr-inhibin exhibited a biopotency of 407 (159:1050; fiducial limits) $\mathrm{U} / \mu \mathrm{g}$ protein and in females the biopotency was $358(226: 565) \mathrm{U} / \mu \mathrm{g}$ protein. These potencies are lower than that measured in the in-vitro bioassay (1120 (1040:1210) $\mathrm{U} / \mu \mathrm{g}$ protein) and differences between in-vivo and in-vitro systems were attributed to the use of bFF rather than a purified human inhibin preparation as standard. These results indicate that hr-inhibin behaves similarly in vivo to bFF. Furthermore, based on the large working range and relatively good precision, the female rat system provides a good basis for an inhibin in-vivo bioassay method.
\end{abstract}

Keywords: inhibin; bioassay; in vivo; in vitro; rat

\section{Introduction}

Inhibin, a disulphide-linked heterodimer which preferentially suppresses FSH secretion, has been purified from several species and its amino acid sequence deduced by recombinant DNA methods (for reviews, see de Jong, 1988; Ying, 1988; de Kretser \& Robertson, 1989). However, the isolation of inhibin from human sources (e.g. follicular fluid) has not been possible owing to limited availability and low inhibin concentrations (McLachlan et al., 1986; Robertson et al., 1990). There is a paucity of information concerning the actions of purified inhibin preparations in vivo due to the small yields. In a previous study, bovine inhibin of $M_{\mathrm{r}} 31000$ was shown to suppress serum FSH to $69 \%$ of control with a nadir occurring at 4-8 h (Findlay et al., 1987).

Human inhibin $\mathrm{A}$ has been produced by recombinant DNA methods, purified and characterized (Tierney et al., 1990). It consists of two subunits ( $\alpha$ and $\beta A$ ) in two molecular weight forms (31 000 and 34000 ). Both forms are similar based on a number of physicochemical characteristics with the difference in molecular weight attributed to differences in glycosylation. Both are biologically active in vitro but their biological activities in vivo have not yet been established. 
The aim of this study was to establish the in-vivo biological activity of human recombinant inhibin A (hr-inhibin) by assessing its effects on serum FSH and LH concentrations of male and female rats and to obtain information concerning its duration of action.

\section{Materials and Methods}

Animals. Male and female Sprague-Dawley rats were obtained from the Monash University Central Animal House. The experiments were performed in the Department of Anatomy (male rats) and the Prince Henry's Institute of Medical Research (female rats).

Inhibin preparations. Bovine follicular fluid (bFF), collected from ovaries obtained at a local abattoir, was treated with dry charcoal (Norit $\mathrm{A}, 100 \mathrm{mg} / \mathrm{ml} \mathrm{bFF}$ ) at $4^{\circ} \mathrm{C}$ for $1 \mathrm{~h}$ and then centrifuged at $10000 \mathrm{~g}$ for $30 \mathrm{~min}$. The pellet was washed with water and the supernatants combined, filtered through filter paper to remove debris and adjusted to the original volume with water. Aliquants were stored at $-20^{\circ} \mathrm{C}$. The same bFF (QC2) pool was used in the in-vitro and in-vivo bioassay studies, although a separate bFF pool, prepared as described above, was used in the time course experiment.

Human recombinant inhibin A was obtained from Biotech Australia Pty Ltd (Sydney, Australia). It was purified from a recombinant mammalian cell line and characterized as previously described (Tierney et al,, 1990). The preparation used (Batch 5) consisted of a mixture of two molecular weight forms $(31000$ and 34000$)$ of inhibin of similar bioactivities in vitro. Based on Coomassie staining after electrophoresis on $15 \%$ polyacrylamide gels the proportion of hr-inhibin of $M_{\mathrm{r}} 31000$ was between 80 and $90 \%$. The hr-inhibin preparation was originally stored in $\sim 35 \%$ acetonitrile $/ 0 \cdot 1 \%$ trifluoroacetic acid at $-70^{\circ} \mathrm{C}$. As required, a sample was thawed, bovine serum albumin $(0 \cdot 1 \%$ final concentration) added, the acetonitrile removed by evaporation under nitrogen and the remaining sample gel-filtered (Sephadex G25, PD 10 columns; Pharmacia, Uppsala, Sweden) in Dulbecco's phosphate buffer pH $7 \cdot 2$. Aliquants of the inhibin fraction were stored at $-70^{\circ} \mathrm{C}$.

Experimental design. The rat experimental designs used are based on previously published observations (Nandini et al., 1976; de Jong et al., 1979; Channing et al., 1981) describing the in-vivo effects of follicular fluid treatment on serum FSH concentrations. In this study, the criteria used for choosing the male rat system (33-35 days old, 3-day castrated) were based on (a) a small animal; (b) castration to remove the complicating effects of gonadal factors including steroids, endogenous inhibin and to elevate serum FSH concentrations; (c) 35 days of age because serum FSH concentrations are highest in this period; and (d) intravenous administration to increase biological effects of inhibin. The female rat system was based on the studies of de Jong et al. (1979), largely without modification. Bovine FF was included as a reference preparation in all systems as it contains inhibin activity in high concentrations (in comparison with human FF in which the levels are low) and has been used previously (e.g. de Jong et al., 1979) in inhibin in-vivo experiments. Furthermore, the inclusion of bFF as reference in the experimental design permitted the quantitation of inhibin activity in the various assay systems.

Male rats. Male rats (31-32 days of age, wt range 90-120 g) were castrated under ether anaesthesia. After 3 days, the rats were treated with an inhibin preparation or saline via the jugular vein. Doses were adjusted for differences in body weight. Trunk blood was collected after decapitation and allowed to clot overnight at $4^{\circ} \mathrm{C}$. The serum was stored at $-20^{\circ} \mathrm{C}$.

For the time course study after injection of bFF $(100 \mu \mathrm{l} / 100 \mathrm{~g}$ body wt $)$, hr-inhibin $(10 \mu \mathrm{g} / 100 \mathrm{~g} \mathrm{body} \mathrm{wt)} \mathrm{or}$ saline $(100 \mu \mathrm{l} / 100 \mathrm{~g}$ body $\mathrm{wt})$, rats $(5-8 /$ group) were killed at $1,2,4,8,12,16$ or $26 \mathrm{~h}$ (bFF) or $2,4,6,8,16$ or $24 \mathrm{~h}$ (hr-inhibin).

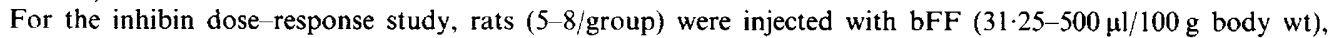
$\mathrm{hr}$-inhibin $(0 \cdot 625 \cdot 40 \mu \mathrm{g} / 100 \mathrm{~g}$ body wt $)$ or solvent $(500 \mu \mathrm{l} / 100 \mathrm{~g}$ body wt $)$ and killed $5 \mathrm{~h}$ later.

Female rats. To study the inhibin dose-response female rats $(81-85$ days of age, $220 \pm 30 \mathrm{~g})$ were ovariectomized under ether anaesthesia. After 2 days, the rats (6-7/group) were injected i.p. with bFF (125-500 $\mu$ l) or hr-inhibin $(2 \cdot 5-20 \mu \mathrm{g})$ and killed $8 \mathrm{~h}$ later. Trunk blood was collected and serum stored at $-20^{\circ} \mathrm{C}$.

Assays. Serum rat FSH and LH concentrations were determined using radioimmunoassay reagents provided by the NIADDK, Bethesda, MD, USA. FSH was assayed utilizing iodinated rat FSH (NIADDK rFSH-I5 or -I7) as tracer, rat FSH antiserum (NIADDK anti-rFSH-S11 (male rat study) or an in-house antiserum in the female rat study (Gibson $e t$ al., 1979)) and rFSH-RP-2 as standard. The within- and between-assay variations were $<5 \%$ and $<10 \%$ respectively. The sensitivity was $3 \mathrm{ng} / \mathrm{ml}$.

LH was assayed utilizing iodinated rat LH (NIADDK rLH-I7) as tracer, rat LH antiserum (NIADDK anti-rLHS9 or S10) and rLH-RP2 as standard. The within- and between-assay variations were $<7 \%$ and $<10 \%$, respectively. All samples from one experiment were assayed in the one assay. Sensitivity was $2 \mathrm{ng} / \mathrm{ml}$.

The inhibin in-vitro bioassay method of Scott et al. (1980) was used with an in-house bFF preparation (bFF2/4) calibrated in terms of a previously described (Scott et al., 1980) ovine testicular lymph preparation as standard. In terms of the WHO pig inhibin reference preparation $(86 / 690)$, one unit of the bFF standard was equivalent to $25.9 \pm 0.80$ units of $86 / 690$. Sensitivity was $0.0625 \mathrm{U} / \mathrm{ml}$. 


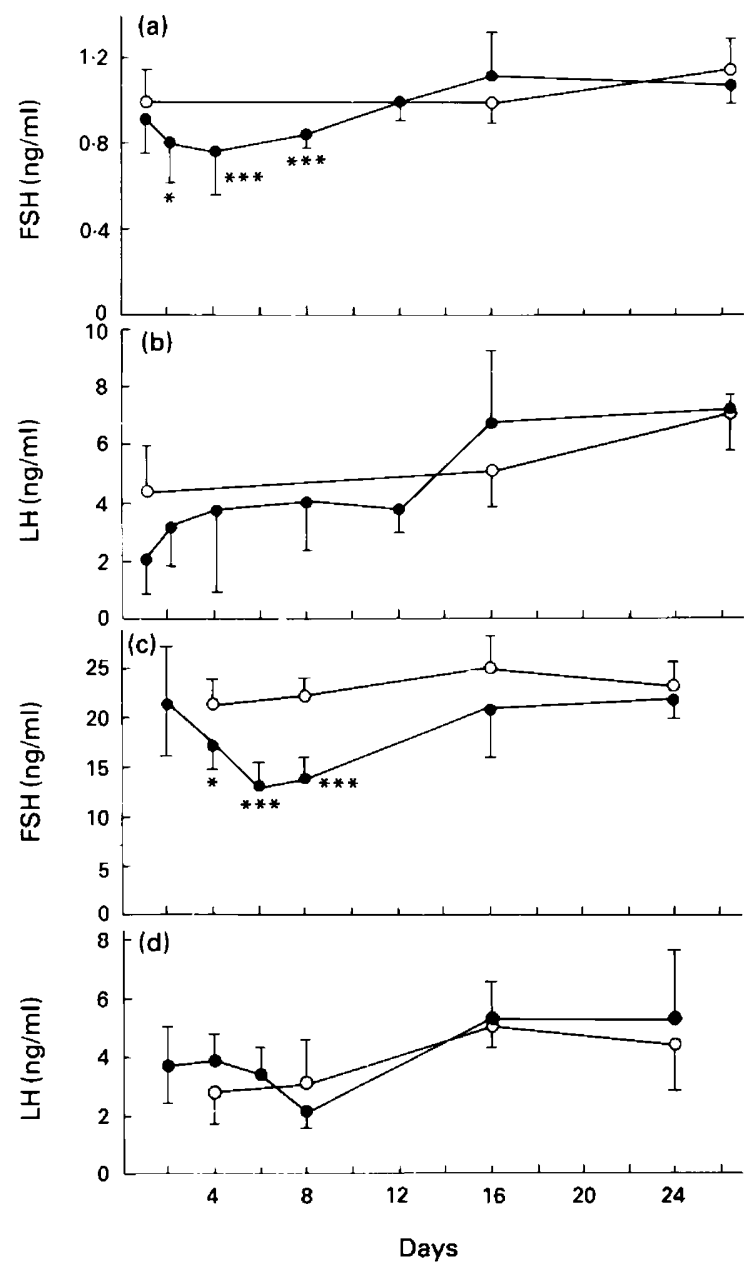

Fig. 1. Time-course effects of bovine follicular fluid (bFF) $(a, b)$ and $\mathrm{hr}$-inhibin (c, d) on serum FSH and LH concentrations in 3-day castrated 35-day-old male rats. bFF $(100 \mu 1 / 100 \mathrm{~g}$ body wt) and hr-inhibin $\left(10 \mu \mathrm{g} / 100 \mathrm{~g}\right.$ body wt) were administered i.v. ${ }^{*} P<0.05,{ }^{* * *} P<0.001$ compared with control values.

Calculations. All bFF and hr-inhibin dose-response data were standardized as a percentage of control values as a means of comparing assay characteristics between systems. An assessment of regression, linearity, precision and relative potency was performed using in-house computer programs based on the methods of Finney (1971). When visual evidence of a dose-response effect was observed, potency estimates were determined based on at least 2 doses of bFF standard and 2-3 doses of hr-inhibin with the exception of Exp. 2 in the study of female rats in which the highest dose of the standard only was used. This approach was justified as it was shown in Exp. 1 that the bFF and hr-inhibin dose-response curves were parallel.

Comparisons between groups were performed using the Peritz multiple comparison test for differences among group means (Harper, 1984).

\section{Results}

\section{Time-course effects in male rats}

A single i.v. injection of bFF and hr-inhibin to 3-day castrated rats resulted in a fall $(P<0.05-$ $P<0.001$ ) in serum FSH after 4-8 h, returning to reach control FSH concentrations by $16-26 \mathrm{~h}$. No rebound effects of inhibin on FSH were observed. Serum LH concentrations were unaffected (Fig. 1). 

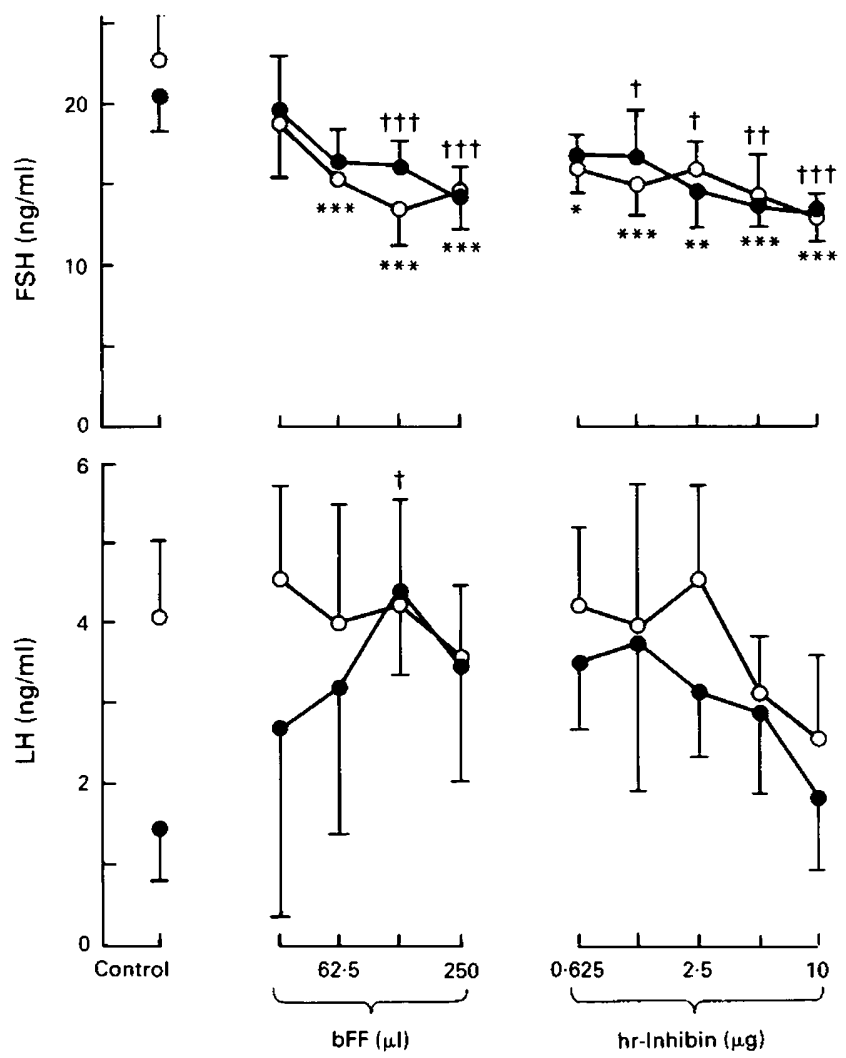

Fig. 2. Dose-response effects of bFF and hr-inhibin on serum FSH and LH $5 \mathrm{~h}$ after administration to 3-day-castrated, 35-day-old male rats. Results of Exps $1(O)$ and $2(0)$ (see Table 1) are presented. ${ }^{*} P<0.05,{ }^{* *} P<0.01,{ }^{* * *} P<0.001 ; \dagger P<0.05,+\dagger P<0.01,+\dagger \dagger P<0.001$ compared with control values.

\section{In-vivo dose-response in male rats}

bFF (31.3-250 $\mu \mathrm{l})$ and $\mathrm{hr}$-inhibin $(0 \cdot 625-10 \mu \mathrm{g})$ administered to 3-day castrated rats resulted in a significant dose-related decline in serum FSH concentrations after $5 \mathrm{~h}$ (Fig. 2; Table 1). Higher doses of bFF $(500 \mu \mathrm{l} / 100 \mathrm{~g}$ body wt) and hr-inhibin $(20-40 \mu \mathrm{g} / 100 \mathrm{~g}$ body wt) showed no further suppression below $50 \%$ of control values (data not shown). Serum $\mathrm{LH}$ concentrations showed no dose-related changes with bFF or hr-inhibin, although isolated differences were observed in one experiment (Fig. 2).

\section{In-vivo dose-response in female rats}

Graded doses of bFF $(125-500 \mu \mathrm{l})$ and hr-inhibin $(2 \cdot 5-20 \mu \mathrm{g})$ administered to 2-day ovariectomized rats resulted in a significant fall in serum FSH to $30 \%$ of control values after $8 \mathrm{~h}$, while LH concentrations were unaffected (Fig. 3).

\section{Analysis of dose-response relationships}

To determine the in-vivo biopotency of hr-inhibin, the bFF preparation was assigned an in-vivo biopotency based on its in-vitro activity (Table 1). Various characteristics of the dose-response curves for bFF and hr-inhibin in the male and female rat systems are summarized in Table 1 . The biopotency of hr-inhibin in terms of bFF in the in-vitro bioassay was $1120(1040: 1210) \mathrm{U} / \mu \mathrm{g}$ protein (weighted mean and $95 \%$ fiducial limits). 
Table 1. In-vivo and in-vitro characteristics of bovine follicular fluid (bFF) and human recombinant inhibin (hr-inhibin)

\begin{tabular}{|c|c|c|c|c|c|c|}
\hline Assay & Preparation & $\begin{array}{l}\text { No. of } \\
\text { exps }\end{array}$ & Potency* & Slope $†$ & $\begin{array}{l}\text { Index of } \\
\text { precision }\end{array}$ & $\sigma \ddagger$ \\
\hline \multirow{2}{*}{$\begin{array}{l}\text { In-vitro } \\
\text { bioassay }\end{array}$} & bFF & 4 & $5980(5770: 6200) \mathrm{U} / \mathrm{ml}$ & $-22 \cdot 4$ & 0.055 & $2 \cdot 8$ \\
\hline & hr-Inhibin & 4 & $\begin{array}{l}\text { 1120(1040:1210) } \\
\mathrm{U} / \mu \mathrm{g} \text { protein }\end{array}$ & $-22 \cdot 7$ & 0.066 & $3 \cdot 3$ \\
\hline \multicolumn{7}{|c|}{ In-vivo bioassay using bFF as standard§ } \\
\hline \multirow[t]{2}{*}{ Male rat } & hr-Inhibin & $\begin{array}{l}1 \\
2\end{array}$ & $\begin{array}{l}471(199: 1824) \mathrm{U} / \mu \mathrm{g} \\
355(131: 1416) \mathrm{U} / \mu \mathrm{g}\end{array}$ & $\begin{array}{l}-8 \cdot 5 \\
-5.9\end{array}$ & $\begin{array}{l}0.65 \\
0.70\end{array}$ & $\begin{array}{c}12 \cdot 5 \\
9 \cdot 41\end{array}$ \\
\hline & & & $407(159: 1050) \mathrm{U} / \mu \mathrm{g}$ & $-7 \cdot 2$ & 0.68 & $11 \cdot 0$ \\
\hline \multirow[t]{2}{*}{ Female rat } & hr-Inhibin & $\begin{array}{l}1 \\
2\end{array}$ & $\begin{array}{l}334(211: 576) U / \mu g \\
476(307: 1437) U / \mu g\end{array}$ & $\begin{array}{l}-42.9 \\
-45.8\end{array}$ & $\begin{array}{l}0.20 \\
0.22\end{array}$ & $\begin{array}{l}19 \cdot 8 \\
22 \cdot 8\end{array}$ \\
\hline & & & $358(226: 565) \mathrm{U} / \mu \mathrm{g}$ & $-44 \cdot 4$ & $0 \cdot 21$ & $21 \cdot 3$ \\
\hline \multicolumn{2}{|c|}{ Combined potency } & 4 & $367(246: 547) \mathrm{U} / \mu \mathrm{g}$ protein & & & \\
\hline
\end{tabular}

*Weighted mean $\pm 95 \%$ fiducial limits.

†Slope of combined regression lines.

$\ddagger$ Standard error term derived from analysis of variance.

$\S$ Defined in terms of its in-vitro activity.

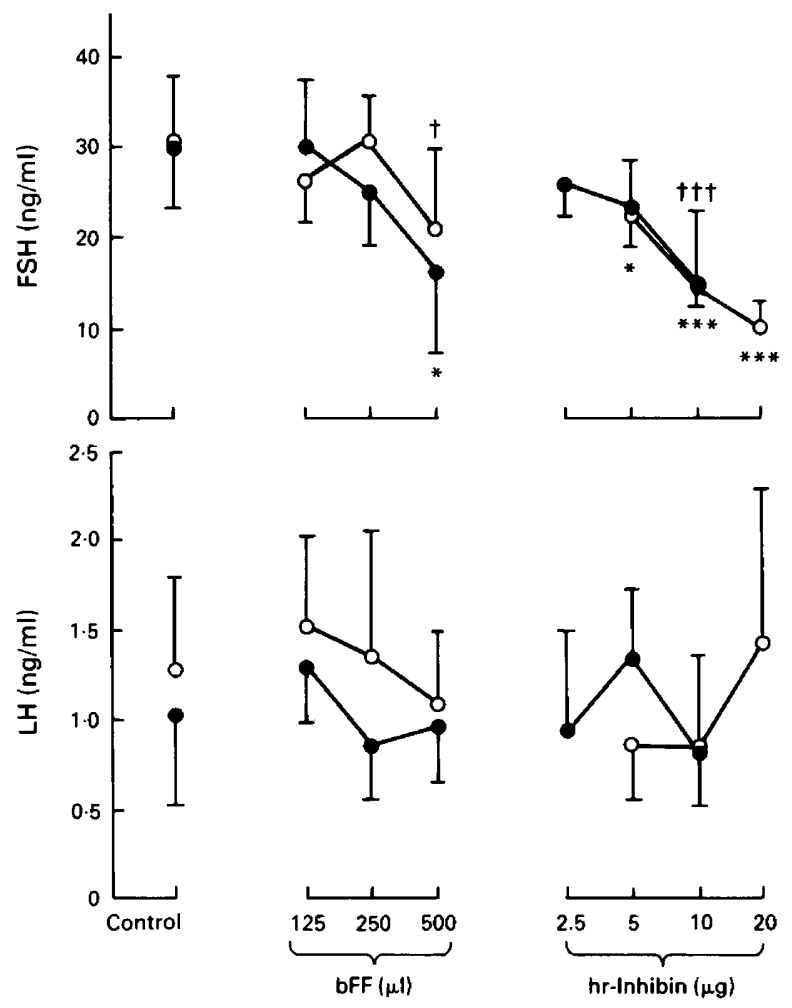

Fig. 3. Dose-response effects of bFF and hr-inhibin on serum FSH and LH $8 \mathrm{~h}$ after administration to 2-day ovariectomized 85-day-old female rats. Results of Exps $1(0)$ and $2(0)$ (see Table 1) are presented. $\left.{ }^{*} P<0.05,{ }^{* * *} P<0.001,+P<0.05,{ }^{+}+\dagger P<0.001\right)$, compared with controls. 
In the male rat system a biopotency of $407(159: 1050) \mathrm{U} / \mu \mathrm{g}$ protein was obtained. The poor precision as assessed by the index of precision $(0.65,0 \cdot 70)$ is associated with the limited slope of the dose-response line although the regression of the line was significant $(P<0.001)$.

In the female rat system, a biopotency of $358(226: 565) \mathrm{U} / \mu \mathrm{g}$ protein was obtained. The slope of the standardized response line was steeper $(b=-44.4, P<0.001)$ than in the male $(b=-7 \cdot 2)$, resulting in a lower index of precision $(0 \cdot 21)$. The dose of hr-inhibin giving the first significant decrease in serum FSH was $>2.5 \mu \mathrm{g}$ in the female rat while the male rats were more sensitive $(<0.625 \mu \mathrm{g})$ to inhibin.

\section{Discussion}

Human recombinant inhibin and bFF suppress serum FSH concentrations in a dose-dependent manner with minimal effects on serum LH in male and female gonadectomized rats. The time course of FSH suppression for both inhibin preparations demonstrates a maximum suppression of serum FSH at 4-8 h, returning to control values by $16-24 \mathrm{~h}$. These features are similar to the action of inhibin of $M_{\mathrm{r}} 31000$ purified from bFF and administered to ovariectomized ewes (Findlay et al., 1987). However, the characteristics of the inhibin dose-response effects for both bFF and hrinhibin in the two sexes differ. The limited suppressive effect of bFF on serum FSH concentrations in male, compared with female, rats has been reported previously (de Jong et al., 1979). The basis for this limited suppression is unknown although the degree of suppression also differs at different ages. For example, a more marked suppression was observed with castrated 15-day-old rats than for castrated 75-day-old rats (de Jong et al., 1979).

One possible explanation involving the role of testosterone arises from passive immunization studies with inhibin-neutralizing antisera in adult male rats treated with the cytotoxin, ethane dimethane sulphonate (EDS: Culler \& Negro-Vilar, 1988; Culler, 1989). EDS selectively destroys Leydig cells, resulting in a dramatic fall in testosterone production. In these studies, passive immunization of adult control animals failed to result in a rise of serum FSH, while causing a rise of serum FSH in EDS-treated or immature male rats. These findings suggest that testosterone antagonizes the inhibitory effects of inhibin on FSH secretion and may explain the failure to observe a complete suppression of serum FSH in castrated rats in the present study.

No significant dose-related changes in serum LH concentrations were observed with bFF or hr-inhibin in this study. It is known that LH secretion in the rat is markedly episodic (Steiner et al., 1982) and so single blood samples from rats, as in this study, will result in large within-group errors in LH measurements. While inhibin has limited effects on basal secretion of LH in vitro (Farnworth et al., 1988a), it does have suppressive effects on the GnRH-stimulated LH secretion in vitro (Farnworth et al., 1988b).

The in-vitro $(1120 \mathrm{U} / \mu \mathrm{g})$ and in-vivo $(367 \mathrm{U} / \mu \mathrm{g})$ biopotencies of hr-inhibin are reasonably comparable considering the variables involved in the determinations. First, the standard used was a follicular fluid preparation from a different species (bovine). Second, the predominant inhibin forms in bFF are larger $\left(M_{\mathrm{r}}>58000\right.$ inhibin; Miyamoto et al., 1986; Robertson et al., 1986) and so may exhibit different biological responses in vivo (e.g. a longer circulating half-life) than the hr-inhibin of $M_{\mathrm{r}} 30000-34000$ although bovine inhibins of $M_{\mathrm{r}} 31000$ and 58000 have been shown to exhibit similar in-vitro potencies (Robertson et al., 1986). Thirdly, other activities (activin, FSH-suppressing protein/follistatin; for reviews see de Jong, 1988; Ying, 1988; de Kretser \& Robertson, 1989) have been identified in bFF which may contribute to the difference in potency estimate, although their contributions are likely to be small. Potency differences of this magnitude between in-vivo and in-vitro activities have been observed previously with human gonadotrophins (Storring \& Gaines Das, 1989).

The female rat system provides a good basis for an inhibin in-vivo bioassay as originally proposed by de Jong et al. (1979). The working range is relatively large (2.5-20 $\mu \mathrm{g} \mathrm{hr}$-inhibin) with a maximum suppression to at least $30 \%$ of control values with a reasonably steep slope to give 
acceptable precision indices $(0 \cdot 2)$. This system is less sensitive $(2 \cdot 5 \mu \mathrm{g})$ than that observed in the male $(<0.625 \mu \mathrm{g})$ and may relate to the mode of delivery (i.p. $v s$ i.v.) and age of animal. To make this system more practical a shorter time interval, e.g. $5 \mathrm{~h}$, is required. On the other hand, the male rat system is too imprecise to use as an in-vivo assay system due to the shallow slope of the doseresponse curve, resulting in high indices of precision and very large fiducial limits. The index of precision values $(0 \cdot 6-0.7)$ are not considered acceptable in parallel line assay systems; however, while the potency values are imprecise, they are broadly similar to those obtained with the female rat system, suggesting that the inhibin responses are similar in both sexes.

In conclusion, these studies have shown that hr-inhibin exhibits FSH-suppressing activity similar to that seen with bFF and purified native bovine inhibin. The similar in-vivo pattern of response of $\mathrm{hr}$-inhibin and bFF and their similar relative activities both in vivo and in vitro indicates that hr-inhibin can be used to explore the physiology of inhibin in vivo.

We thank L. Clarke, N. Cahir, D. Russell and L. M. Foulds for excellent technical assistance; and Biotech Australia $\mathrm{P} / \mathrm{L}$ for the generous provision of hr-inhibin. The study was funded by grants from the National Health and Medical Research Council of Australia.

\section{References}

Channing, C.P., Hoover, D.J., Anderson, L.D. \& Tanabe, K. (1981) Control of follicular secretion of inhibin in vitro and in vivo. In Non-Steroidal Regulators in Reproductive Biology and Medicine, pp. 41-55. Eds T. Fujii \& C. P. Channing. Pergamon Press, New York.

Culler, M.D. (1989) Abolition of endogenous testosterone secretion is necessary to reveal a suppressive effect of endogenous inhibin on FSH secretion in adult male rat. Proc. 71st Mtg Endocrine Society, p. 171, Abstr. 595.

Culler, M.D. \& Negro-Vilar, A. (1988) Passive immunoneutralization of endogenous inhibin: sex-related differences in the role of inhibin during development. Molec. cell. Endocr. 58, 263-273.

de Jong, F.H. (1988) Inhibin. Physiol. Rev. 68, 555-607.

de Jong, F.H., Welschen, R., Hermans, W.P., Smith, S.D. \& van der Molen, H.J. (1979) Effects of factors from ovarian follicular fluid and Sertoli cell culture medium on in-vivo and in-vitro release of pituitary gonadotrophins in the rat: an evaluation of systems for the assay of inhibin. J. Reprod. Fert., Suppl. 26, 47-59.

de Kretser, D.M. \& Robertson, D.M. (1989) The isolation and physiology of inhibin and related proteins. Biol. Reprod. 40, 33-47.

Farnworth, P.G., Robertson, D.M., de Kretser, D.M. \& Burger, H.G. (1988a) Effects of $31 \mathrm{kDa}$ bovine inhibin on FSH and LH in rat pituitary cells in vitro: actions under basal conditions. Endocrinology 122, 207-213.

Farnworth, P.G., Robertson, D.M., de Kretser, D.M. \& Burger, H.G. (1988b) The effects of $31 \mathrm{kDa}$ bovine inhibin on FSH and $\mathrm{LH}$ in rat pituitary cells in vitro: antagonisms of gonadotrophin-releasing hormone agonists. J. Endocr. 119, 233-241.

Findlay, J.K., Robertson, D.M. \& Clarke, I.J. (1987) Influence of dose and route of bovine follicular fluid and the suppressive effect of purified bovine inhibin $\left(M_{\mathrm{r}} 31000\right)$ on plasma FSH concentrations in ovariectomized ewes. J. Reprod. Fert. 80, 455-461.
Finney, D.J. (1971) Statistical Method in Biological Assay. Griffin, London.

Gibson, W.R., Ingram, B.W. \& Lee, V.W.K. (1979) Can reduced consumption of gonadotrophins account for ovarian compensation in unilaterally ovariectomized, immature mice injected with gonadotrophin? $J$. Reprod. Fert. 57, 209-218.

Harper, J.F. (1984) Peritz' F test: basic program of a robust multiple comparison test for statistical analy. sis of all differences among group means. Comput. Biol. Med. 14, 437-445.

McLachlan, R.I., Robertson, D.M., Burger, H.G. \& de Kretser, D.M. (1986) The radioimmunoassay of bovine and human follicular fluid and serum inhibin. Molec. cell. Endocr. 46, 175-185.

Miyamoto, K., Hasegawa, Y., Fukuda, M. \& Igarashi, M. (1986) Demonstration of the molecular weight forms of inhibin in bovine follicular fluid (bFF) by using monoclonal antibodies to bFF $32 \mathrm{~K}$ inhibin. Biochem. Biophys. Res. Commun. 136, 1103-1109.

Nandini, S.G., Lipner, H. \& Moudgal, N.R. (1976) A model system for studying inhibin. Endocrinology $\mathbf{9 8}$, $1460-1465$.

Robertson, D.M., de Vos, F.L., Foulds, L.M., McLachlan, R.I., Burger, H.G., Morgan, F.J., Hearn, M.T.W. \& de Kretser, D.M. (1986) Isolation of $31 \mathrm{kDa}$ form of inhibin from bovine follicular fluid. Molec. cell. Endocr. 44, 271-277.

Robertson, D.M., Foulds, L.M., de Vos, F., Leversha, L. \& de Kretser, D.M. (1990) Identification of inhibin and inhibin-related proteins in human follicular fluid. Reprod. Fert. Develop. 2, 327-335.

Scott, R.S., Burger, H.G. \& Quigg, H. (1980) A simple and rapid in vitro bioassay for inhibin. Endocrinology 107, 1536-1542.

Steiner, R.A., Bremner, W.J. \& Clifton, D.K. (1982) Regulation of luteinizing hormone pulse frequency and amplitude by testosterone in the adult male rat. Endocrinology 122, 959-964.

Storring, P.L. \& Gaines Das, R.E. (1989) The International Standard for Pituitary FSH: Collaborative 
study of the Standard and of four other human FSH preparations of differing molecular composition by bioassays, receptor assays and different immunoassay systems. J. Endocr. 123, 275-293.

Tierney, M.L., Goss, N.H., Tomkins, S.M., Kerr, D.B., Pitt, D.E., Forage, R.G., Robertson, D.M., Heam, M.T.W. \& de Kretser, D.M. (1990) Physicochemical and biological characterization of recombinant human inhibin A. Endocrinology 126, 3268-3270.

Ying, S.-Y. (1988) Inhibins, activins and follistatins: gonadal proteins modulating the secretion of folliclestimulating hormone. Endocr. Rev. 9, 267-290.

Received 8 June 1990 